\title{
Levels of cobalt and silver in water sources in a mining area in Ghana
}

\author{
D. K. ESSUMANG \\ Environmental Research Group, Department of Chemistry, University of Cape Coast, Cape Coast. Ghana. \\ E-mail: kofiessumang@yahoo.com,dessumang@ucc.edu.gh
}

\begin{abstract}
The study reported herein looked at the quality of drinking water sources (underground water and river water) from a mining community in Ghana. The water samples were treated in the laboratory by acid digestion and the concentration of silver and cobalt were analysed with Atomic Absorption Spectrophotometer. The results of the analysis indicated that all the water sources of Bogoso-Domase analyzed had levels of silver and cobalt above US-EPA limit $0.01 \mathrm{mg} / \mathrm{L}$ of silver and $0.079 \mathrm{mg} / \mathrm{L}$ of cobalt. The high mean concentration of cobalt in the underground and the river water sources may have been responsible for a deep blue colour change of the water whenever it got into contact with tannin in plant, hence affecting the cooking of certain foodstuffs such as cassava and plantain. However, these metals are seldomly discussed when it comes to those metals of concern of mining pollution. This calls for extensive research into the lesser known metals in the mining environment which might equally pose health problems since some of the studies on their cancer effect on people are inconclusive.
\end{abstract}

(C) 2009 International Formulae Group. All rights reserved.

Keywords; Biomagnifies, photographic industry, Telluride, Argyria, Tannin, Dumase, Bogoso.

\section{INTRODUCTION}

Underground waters are generally free from suspended solids and microorganisms. They, however, contain more of dissolve salts and quite often cause the problem due to hardness and other heavy metals (Bhatia, 2002). Currently, waterborne toxic chemicals pose the greatest threat to the safety of water supplies in industrialized nations. This is particularly true of ground water which exceeds in volume the flow of all rivers, lakes and streams (Bhatia, 2002). Heavy metal pollution is caused when such metals as arsenic, cobalt, copper, cadmium, lead, silver and zinc contained in excavated rock or exposed in an underground mine come in contact with water. Metals are leached out and carried downstream as water washes over the rock surface. Although metals can become mobile in neutral $\mathrm{pH}$ conditions, leaching is particularly accelerated in the low $\mathrm{pH}$ conditions such as are created by Acid Mine Drainage.

Gold mining in Ghana has been the largest foreign exchange earner apart from cocoa, since pre- and post-independent Ghana. According to Tenkorang (2000), gold export earning rose from 107.9 million dollars to 744.2 million dollars between 1985 and 1989 (Obiri et al., 2006).

The presence of the metal in water bodies is insufficient evidence of pollution; the relative concentration is all important (Alloway and Ayres, 1997). An ICP scan of tailings dam revealed elevated levels of numerous trace metals such as aluminium, cadmium, cobalt and nickel in a spring water (Hobbs and Cobbing, 2007). These metals are found in soils and rocks. Even rain water with its acidic $\mathrm{pH}$ can cause heavy metals to leach into water bodies (Duker et al., 2004). Cobalt 
and nickel are essential trace metals in human diet. They are also major components of the alloys employed in the plate and screw used for connecting bones in orthopedic surgery and in the manufacture of artificial organs (Kocijan et al., 2004). Cobalt is used also as coloring agents for pottery, ceramics, and glass. However, excessive amounts of these transitional metal ions are toxic. For example, cobalt and nickel salts have been reported to induce convulsions (Papp et al., 1987; Wright and Welbourn, 2002), and to cause DNA strand breaks (Christie and Tummolo, 1989), and to be organ toxic (Xie et al., 1995). Cobalt salts are thought to promote the oxidation of reduced glutathion (Iscan et al., 1994) to produce reduction in the number of hepatic hem proteins such as cytochrom P 450 and to interfere with heme metabolism by accelerating its breakdown and inhibiting its synthesis (Nakamura et al., 1975). Cobalt was found also obviously harmful on the prenatal development of mice, rats and rabbits (Szakmary et al., 2001).

Health effects that arise as a result of the uptake of high concentrations of cobalt are: vision problems, heart problems, thyroid damage, impaired lung function, dermatitis and cardiovascular effects (IARC, 1991, 2003). Studies in animals suggested that children may absorb more cobalt than adults from food and liquid containing cobalt (ATSDR, 2004).

Silver is normally present at trace concentrations in water. It tends to accumulate in sediments in aquatic systems because of its tendency to form insoluble complexes. Silver is naturally occurring in the earth's crust at trace concentrations of $0.1 \mathrm{mg} / \mathrm{kg}$ (Fisher et al., 1984; ASTDR, 1989). In rock and soil, silver is mainly found in sulphide compounds in association with lead, iron, telluride or gold. It is rarely found in its metallic state (Purcell and Peters, 1998).

Silver is not an essential element. It is excreted in faeces, urine and perspiration. It may also accumulate in the hair and bones. The most commonly reported effect of silver in humans is argyria (skin discolouration) which is cosmetic rather than toxic (Purcell and Peters, 1998). Silver toxicity in aquatic systems is related to free ion $\left(\mathrm{Ag}^{+}\right)$activity. The $\mathrm{Ag}^{+}$ion is surface active and does damage to aquatic organisms by binding to specific sites on or in the gills. Ligands such as humic substances, chloride and sulphide ions bind silver and decrease the activity of the free ion and therefore, the toxicity of the metal. Death, low productivity and altered reproduction have been demonstrated in laboratory experiments with both plants and animals as a result of silver toxicity (Purcell and Peters, 1998).

What makes heavy metals particularly dangerous is their tendency to bioaccumulate, meaning they increase in concentration in the bodies or tissues of living organisms over time. They are stored in the tissues at a rate faster than they are metabolized or excreted from the body. Such substances exemplify the often quoted statement that "the dose defines the poison” (Roderick's, 1992).

In Ghana, gold is mined almost everywhere, from the coast to the north of the country and the fact that silver and cobalt are associated with gold mining makes it very important for this study. These metals are seldomly discussed in Ghana when it comes to those metals of concern of mining pollution. At present, water fetched from some of the water sources in the research area gives blue colouration when used to cook foodstuffs containing tannins. This has become a big problem for the inhabitant in the community. The cause of the blue colouration is not known, but Gray (2005) has reported that high concentration of cobalt in water can react with tannin in plant cells and change water colour to deep blue-black, hence this study.

It was in view of this problem that this study was carried out. This study sought to determine the levels of cobalt and silver in water sources in a mining environment.

\section{MATERIALS AND METHODS \\ Study Area}

The study is located at $5^{\circ} 34^{\prime} 21.67^{\prime \prime} \mathrm{N}$ and $2^{\circ} 011^{\prime} 39.33^{\prime \prime} \mathrm{W}$. 
The research was carried out in a rural community called Dumase in Bogoso. This is a mining area in the Wassa West District in the Western Region of the Republic of Ghana Fig. 1. Bogoso town is located $35 \mathrm{~km}$ north of Tarkwa, $85 \mathrm{~km}$ north of the port of Takoradi and approximately $200 \mathrm{~km}$ west of the capital of Ghana, Accra. The source of drinking water for the inhabitant is mainly from bore hole.

\section{Sample collection and treatment}

In all, thirty six water samples were collected during the dry season over 4 week period. Samples of the borehole water and river water were collected into amber bottles that have been pre-washed with detergent and tap water and rinsed thoroughly with distilled water. Nitric acid $\left(\mathrm{HNO}_{3}\right)$ was added to the water samples to break down organic materials and oxidize the metals that might be in the sample. Identification labels were written on the containers for easy identification. The samples were stored in an iced chest and later conveyed to the laboratory where they were stored in a refrigerator at a temperature of about $4{ }^{\circ} \mathrm{C}$.

\section{Digestion procedure for water samples}

About $100 \mathrm{~mL}$ each of the water samples was measured with a measuring cylinder into $150 \mathrm{~mL}$ beakers and $10 \mathrm{~mL}$ each of nitric acid and sulphuric acid were added to them. The mixture was then heated on a heating mantle and allowed to evaporate to about $15-20 \mathrm{~mL}$. The mixture was taken off the heating mantle and allowed to cool to room temperature. The samples were filtered

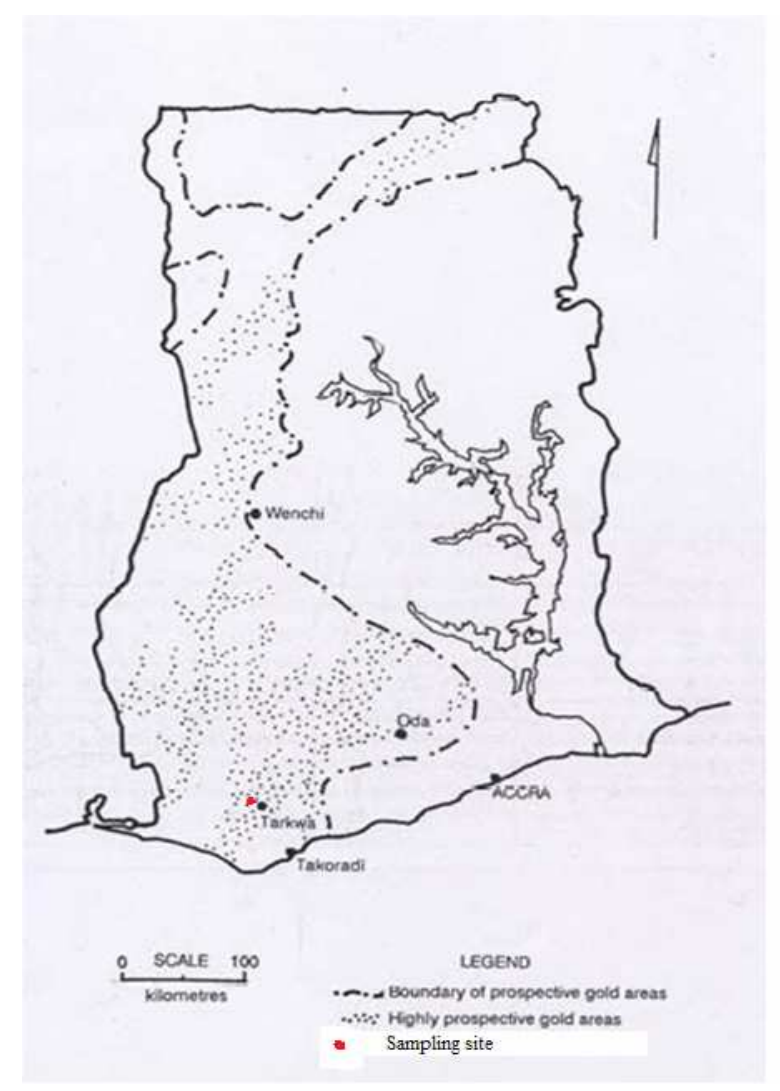

Figure 1: Map of prospective small-scale gold mining regions in Ghana. 
using suction filtration with Whatman's filter paper of pore size $0.45 \mu \mathrm{m}$ to remove any particulate matter that might remain. After this, the final volume was diluted with distilled water to $100 \mathrm{~mL}$ and stored in plastic containers for subsequent analysis with Hewlett Packard - 6890 Atomic Absorption Spectrophotometer (AAS) made in the USA. The samples were analyzed for cobalt and silver using the AAS. The AAS type used was the Agilent (Flame Emission) AAS and has a detection limit of $0.001 \mathrm{mg} / \mathrm{L}$. They were analyzed using acetylene/air in the flame. NIVA 0736 certified reference material Norwegian Institute for Water Research (NIVA) was used for the water samples, though not digested (Whiteside and Milner, 1984; CNLET, 1994; APHA, 1995).

\section{Quality control studies}

For reproducibility studies, certified reference material from NIVA (cobalt of $13.70 \mathrm{ppm}$ and silver of $1.000 \mathrm{ppm}$ ) were analyzed together with the samples. The average concentration of silver and cobalt obtained from the certified reference material analysis are $1.013 \mathrm{mg} / \mathrm{kg}$ and $13.2 \mathrm{mg} / \mathrm{kg}$ respectively. The percentage of silver recovered from the certified reference material ranged between $94-112 \%$ with a standard deviation of 0.0945 and the percentage of cobalt recovered from the certified reference material ranged between $95-98 \%$ with a standard deviation of 0.200 . It shows that the method used in the analysis is very reliable.

\section{RESULTS AND DISCUSSION}

The samples of the water were tested for silver and cobalt. The results of the analysis of silver and cobalt are in Table 1. Table 1 below shows the result of the analysis of the various samples for cobalt. There were appreciable levels (compared with the USEPA limit $0.079 \mathrm{mg} / \mathrm{L}$ ) of cobalt in all the samples analysed. The US-EPA limit 0.079 $\mathrm{mg} / \mathrm{L}$ of cobalt was used as Ghana has not established guideline for cobalt in water bodies.

Table 1 below also shows the result of the analysis of the various samples for silver. There were appreciable levels of silver in all the samples analysed.

\section{Ground water sources Silver}

The results of this research revealed that there is an elevated level of silver in the ground water sources of Bogoso-Domase ranging from 0.032 to $0.049 \mathrm{mg} / \mathrm{L}$ with a mean concentration value of $0.039 \pm 0.005$ $\mathrm{mg} / \mathrm{L}$. The mean concentration of silver $(\mathrm{Ag})$ $(0.039 \mathrm{mg} / \mathrm{L})$ is considered high because according to the United State Environmental Protection Agency (U.S - EPA), the highest amount of silver (Ag) allowed in drinking water is $0.01 \mathrm{mg} / \mathrm{L}$. The concentration of silver found in the borehole water however, exceeded the United State Environmental Protection Agency permissible value of 0.01 $\mathrm{mg} / \mathrm{L}$ by $0.029 \mathrm{mg} / \mathrm{L}$ representing $74.4 \%$. The implication therefore, is that the borehole water is contaminated with silver and must be purified. Members of the communities who drink this water regularly without purification may develop argyria (skin discolouration) over time which has not been proven. It has also been reported that, accumulation of silver appears to result from adsorption rather than uptake with bio-concentration factors of 13,000 and 66,000 (Fisher et al., 1984; ASTDR, 1989).

The elevated level of silver in the borehole water may be due to the gold mining activities within the area, especially, the activities of the illegal miners who are popularly called 'galamsey'. According to Wright and Welbourn (2002), gold mining activities produce silver-enriched waste rocks and slag also high in the concentration of silver into the environment which could contaminate both underground water and surface water bodies within the mining area.

Moreover, silver is an impurity of gold because, according to Smith and Carson (1977), silver is produced as a by-product during the processing of gold in South Africa. Waste solutions containing traces of silver in tailing dams within gold mining areas could also be a possible source of silver contamination of the underground and surface water sources in mining communities.

\section{Cobalt}

Cobalt is one of the elements that have been tested and found in high concentration in the ground water sources in some 
Table 1: Mean concentrations of cobalt and silver in water samples.

\begin{tabular}{lcccccc}
\hline $\begin{array}{l}\text { Dates of sample } \\
\text { collection }\end{array}$ & \multicolumn{3}{c}{$\begin{array}{c}\text { Mean Concentration of Cobalt in } \\
\text { Water Samples mg/L }\end{array}$} & \multicolumn{3}{c}{$\begin{array}{c}\text { Mean Concentration of Silver in } \\
\text { Water Samples mg/L }\end{array}$} \\
\cline { 2 - 7 } & Borehole & $\begin{array}{c}\text { River } \\
\text { Wurawura }\end{array}$ & $\begin{array}{c}\text { River } \\
\text { Aprepre }\end{array}$ & Borehole & $\begin{array}{c}\text { River } \\
\text { Wurawura }\end{array}$ & $\begin{array}{c}\text { River } \\
\text { Aprepre }\end{array}$ \\
\hline March 12, 2008 & 0.095 & 0.184 & 0.182 & 0.035 & 0.066 & 0.013 \\
& 0.090 & 0.183 & 0.175 & 0.034 & 0.058 & 0.012 \\
& 0.100 & 0.176 & 0.186 & 0.032 & 0.062 & 0.010 \\
March 19, 2008 & 0.169 & 0.164 & 0.180 & 0.039 & $<0.001$ & 0.009 \\
& 0.168 & 0.163 & 0.073 & 0.038 & $<0.001$ & 0.004 \\
& 0.166 & 0.167 & 0.068 & 0.040 & $<0.001$ & 0.002 \\
March 26, 2008 & 0.193 & 0.179 & 0.172 & 0.043 & $<0.001$ & $<0.001$ \\
& 0.199 & 0.176 & 0.166 & 0.045 & $<0.001$ & $<0.001$ \\
& 0.197 & 0.174 & 0.169 & 0.049 & $<0.001$ & $<0.001$ \\
April 5, 2008 & 0.217 & 0.188 & 0.166 & 0.039 & $<0.001$ & $<0.001$ \\
& 0.218 & 0.181 & 0.182 & 0.034 & $<0.001$ & $<0.001$ \\
& 0.214 & 0.174 & 0.192 & 0.042 & $<0.001$ & $<0.001$ \\
Mean of means & $\mathbf{0 . 1 6 9}$ & $\mathbf{0 . 1 7 6}$ & $\mathbf{0 . 1 5 9}$ & $\mathbf{0 . 0 3 9}$ & $<\mathbf{0 . 0 1 5}$ & $<\mathbf{0 . 0 0 4}$ \\
Standard & $\mathbf{0 . 0 4 8}$ & $\mathbf{0 . 0 0 8}$ & $\mathbf{0 . 0 4 2}$ & $\mathbf{0 . 0 0 5}$ & $\mathbf{0 . 0 2 7}$ & $\mathbf{0 . 0 0 5}$ \\
deviation & & & & & & \\
\hline Tabulated values are Mean \pm SD (indicated) of 3 determinations
\end{tabular}

mining environment. The concentration of cobalt in the ground water ranged from 0.095 $\mathrm{mg} / \mathrm{L}$ to $0.218 \mathrm{mg} / \mathrm{L}$ with a total mean concentration of $0.169 \mathrm{mg} / \mathrm{L}$ and a standard deviation of 0.048 .

The highest amount of cobalt allowed in drinking water is $0.09 \mathrm{mg} / \mathrm{L}$ as compared to the $0.169 \mathrm{mg} / \mathrm{L}$ found this study. This value exceeded the US-EPA permissible value by $0.079 \mathrm{mg} / \mathrm{L}$ representing 46.7\%, (US-EPA).

The elevated level of cobalt in the ground water may also be due to soils and underground rocks containing cobalt with which rain water runs through or seeps through (acid mine drainage). This is because cobalt occurs naturally in some rocks and even in soils, and water passing through these rocks and soils are likely to be contaminated with cobalt.

Gold mining activities may also be responsible for the high level of cobalt in the borehole water. Cobalt is not mined alone. It is an impurity of many minerals such as nickel, copper and other elements. The gold mining activities in the area could release cobalt-enriched waste rocks and slag containing traces of cobalt into the environment hence contaminating the water or increasing the level of cobalt in the water (Wright and Welbourn, 2002).

Cobalt forms a lot of colour compounds especially blue colour compounds such as $\mathrm{CoSO}_{4} \quad$ (dark blue), $\left[\mathrm{CoBr}\left(\mathrm{NH}_{3}\right)_{5}\right] \mathrm{SO}_{4}$ (aqueous violet), and many more, and could be causing the blue colour change of the borehole water when it is used in cooking. According to Gray (2005), high concentration of elements such as iron, nickel and cobalt in water can react with tannin in plant cells and change water colour to deep blue-black. Once cobalt is found in high concentration in the borehole water, it may be the one causing the blue colour of the borehole water whenever a plantain is placed in the borehole water which makes it (water) unpleasant for drinking.

\section{Surface water sources \\ Silver}

The results revealed that there were high levels of silver in the surface water sources of Bogoso-Domase i.e. River Wurawura, ranging from $<0.001$ to 0.066 
$\mathrm{mg} / \mathrm{L}$ with a mean concentration value of $<0.015 \mathrm{mg} / \mathrm{L}$ and a standard deviation of 0.027 and River Aprepre ranging from < 0.001 to $0.013 \mathrm{mg} / \mathrm{L}$ with a mean concentration value of $<0.004 \mathrm{mg} / \mathrm{L}$ and a standard deviation of 0.005 . The mean concentrations of silver (Ag) in all the water sources analyzed were a bit high (Warrington, 1996).

\section{Cobalt}

The results also revealed that there were high levels of cobalt in the surface water sources of Bogoso-Domase i.e. River Wurawura, ranging from 0.163 to $0.188 \mathrm{mg} / \mathrm{L}$ with a mean concentration value of 0.176 $\mathrm{mg} / \mathrm{L}$ and a standard deviation of 0.008 and River Aprepre ranging from 0.068 to 0.192 $\mathrm{mg} / \mathrm{L}$ with a mean concentration value of $0.159 \mathrm{mg} / \mathrm{L}$ and a standard deviation of 0.042 . The mean concentrations of cobalt (Co) in all the water sources were a bit high.

Cobalt and cancer studies on people are inconclusive (MOE, 2001; Kechrid, 2006). In Ghana, many trace elements in the environment have been well characterized, but very little is known about silver and cobalt levels in the water distribution systems, even though silver ranks among the most toxic to marine invertebrate. Some people who drank large quantities of a beer having high levels of cobalt experienced nausea, vomiting, and serious effects on the heart (MOE, 2001; Chffoleau et al., 2005).

\section{Conclusion}

This research found that the borehole water of Bogoso-Domase had a mean concentration of $0.039 \mathrm{mg} / \mathrm{L}$ of silver which is high than the U.S - EPA permissible value of $0.01 \mathrm{mg} / \mathrm{L}$ of silver in drinking water. The permissible value is exceeded by $0.029 \mathrm{mg} / \mathrm{L}$ representing $74.4 \%$. This borehole water is contaminated with silver and is unwholesome for drinking.

The study also found an elevated level of cobalt in the borehole water with a mean concentration of $0.169 \mathrm{mg} / \mathrm{L}$. This value exceeded the US-EPA permissible of 0.09 $\mathrm{mg} / \mathrm{L}$ by $0.079 \mathrm{mg} / \mathrm{L}$ representing $46.7 \%$. The high concentration of the cobalt in the borehole water may be causing the blue colour change of the borehole water since it can react with tannin in plant cells to give such colour. The other water sources, i.e. River Wurawura and River Aprepre, all had elevated levels of both silver and cobalt with levels higher than the US - EPA values. This, therefore, calls for extensive research into the lesser known metals in the mining environment which might equally pose health problems to avert any possible epidemic.

\section{ACKNOWLEDGEMENTS}

This work was supported by funds provided by the Ghana Government's Book and Research Allowance. The author would like to thank the technical assistance of workers of the FDB-Ghana.

\section{REFERENCES}

Alloway BJ, Ayres DC. 1997. Chemical Principles of Environmental Pollution $\left(2^{\text {nd }}\right.$ edn). Chapman and Hall: 2-6 Boundary Row, London SE $18^{\text {th }}$, UK; 190- 219.

ATSDR (Agency for Toxic Substances and Disease Registry). 2004. Toxicological Profile for Cobalt. Atlanta, GA: U.S. Department of Health and Human Services, Public Health Service.

ASTDR (Agency for Toxic Substances and disease Registry). 1989. Toxicological Profile for Silver. ASTDR/TP-SILV19/24

APHA, AWWA, WEF. 1995. Standard Methods for the Examination of Water and Waste Water $\left(19^{\text {th }}\right.$ edn). APHA, AWWA, WEF: Washington DC; $1-27$, $3-15$.

Bhatia SC. 2002. Environmental Chemistry. Satish Kumar Jain for CBS Publishers \& Distributors: 4596/LA, 11 Darya, Ganj New Dclhim 10002 India; 80 - 100.

Chffoleau J, Auger D, Roux N, Rozuel E, Santini A. 2005. Distribution of silver in mussels and oysters along the French 
coast: Data from the national monitoring program. Marine Pollution Bulletin, 50(12): 1719 - 1723.

Christie NT, Tummolo DM. 1989. The effect of Ni (II) on DNA replication. Biol. Trace Elem. Res., 21: 3- 12.

CNLET (Canadian National Laboratory for Environmental Testing). 1994. Manual of Analytical Methods (Vol 2). CNLET; 02$2451-1$ to $20-2451-14$.

Duker AA, Carranza EJM, Hale M. 2004. Spatial dependency of Buruli ulcer prevalence on arsenic - enriched domains in Amansie West District, Ghana: implication for arsenic mediation in Mycobacterium ulcerans infection. Int. J. Health Geograph., 3: 19-28.

Fisher NS, Bohe M, Teyssie J-L. 1984. Accumulation and toxicity of $\mathrm{Cd}, \mathrm{Zn}, \mathrm{Ag}$ and $\mathrm{Hg}$ in four marine phytoplankters. Mar. Ecol. Prog. Ser., 18: 210-213.

Hobbs PJ, Cobbing JE. 2007. A hydrogeological assessment of acid mine drainage impacts in the West Rand Basin, Gauteng Province. Rep. no. CSIR/NRE/ WR/ER/2007/0097/C. CSIR.

Gray NF. 2005. Water Technology: an Introduction for Environmental Scientists and Engineers ( $2^{\text {nd }}$ edn). Elsevier Butter Worth - Heinemann: London UK; 285 307.

IARC (International Agency for Research on Cancer) - Summaries \& Evaluations. 1991. Cobalt and Cobalt Compounds (Group 2B) (52): 363.

IARC (International Agency for Research on Cancer) - Summaries \& Evaluations. 2003. Cobalt Salts and Cobalt Compounds (Group 2B) (52) : 363.

Iscan M, Coban T, Eke BC. 1994. Differential combined effect of cadmium and nickel on hepatic and renal glutathione Stransferases of the guinea pig. Environ. Health Perspect., 102: 69-72.

Kechrid Z, Dahdouh F, Djabar RM, Bouzerna N. 2006. Combined effect of water contamination with cobalt and nickel on metabolism of albino (Wistar) rats. Iran. J. Environ. Health. Sci. Eng., 3(1): 65-69.

Kocijan A, Milosev I, Pihlar B. 2004. Cobaltbased alloys for orthopaedic applications studied by electrochemical and XPS analysis. Mater Sic. Mater Med., 15: 643650.

MOE (Ontario Ministry of the Environment). 2001. Fact Sheet, Cobalt in the Environment (Volume 3793e). Queen's Printer for Ontario: Ontario; 1-3.

Nriagu JO, Nieboer E. 1988. Advances in Environmental Science and Technology. John Wiley \& Sons: New York, NY; 785

Nakamura M, Yasukochi Y, Minakami S. 1975. Effect of cobalt on heme biosynthesis in rat liver and spleen. Biochem, 78: 373-380.

Purcell TW, Peters JJ. 1998. Sources of silver in the environment: Silver toxicity. Environmental Toxicology and Chemistry, 17(4): 539-546.

Obiri S, Dodoo DK, Okai-Sam F, Essumang DK, Adjorlolo-Gasokpoh A. 2006. Cancer and Non-Cancer Health Risk from Eating Cassava Grown In Some Mining Communities in Ghana. Environmental Monitoring and Assessment, 118: 37-49.

Papp A, Feher O, Erdelyi L. 1987. The ionic mechanism of the pentylenetetrazol convulsions. Acta Biol. Hung., 38: 349361.

Raven PH, Johnson GB. 1999. Biology (5th edn). The McGraw-Hill Companies: Boston; $151-155$.

Reilly C. 1980. Metal Contamination in Food. Applied Science Publisher Ltd.: London; 142.

Rodricks JV. 1992. Calculated Risks: Understanding the Toxicity and Human Health Risks of Chemicals in Our Environment. Cambridge University Press: Cambridge; 1.

Smith IC, Carson BL. 1977. Trace Metals in the Environment, Volume 2 Silver. Ann Arbor Sci, Public Ann Arbor, MI; 469.

Szakmary E, Ungvary G, Hudak A, Naray M, Morvai V. 2001. Effects of cobalt 
sulphate on prenatal development of mice, rats and rabbits and on early postnatal development of rats. Toxico. Enver. Health, 62: 367-386.

Tenkorang CO. 2000. April, 19th Mining and the Environment, Daily Graphic Col 2-6, p. 7 .

Warrington PD. 1996. Ambient Water Quality Criteria for Silver. Ministry of Environment, Lands and Parks, Water Quality Branch: Victoria, BC.

Whiteside PJ, Milner BA. 1984. Atomic Absorption Data Book. Pye Unicam Ltd.
Wright DA, Welbourn P. 2002. Environmental Toxicology. Cambridge University press: Cambridge; 249 - 345.

Xie J, Funakoshi T, Shimada H, Kojima S. 1995. Effects of chelating agents on testicular toxicity in mice caused by acute exposure to nickel. Toxicology, 103: 147155.

Zumdahl SS. 1997. Chemistry; Instructor's Annotated Edition (4 ${ }^{\text {th }}$ edn). Houghton Mifflin Company: Boston, New York; $631-632$. 